\title{
Universiteit
}

Leiden

The Netherlands

\section{What is wrong with pagan studies?}

Davidsen, M.A.

\section{Citation}

Davidsen, M. A. (2012). What is wrong with pagan studies? Method \& Theory In The Study Of Religion, 24(2), 183-199.

doi:10.1163/157006812X634881

Version:

Publisher's Version

License:

Licensed under Article 25fa Copyright Act/Law (Amendment Taverne)

Downloaded from: $\quad$ https://hdl.handle.net/1887/3160767

Note: To cite this publication please use the final published version (if applicable). 


\title{
Review Essay
}

\section{What is Wrong with Pagan Studies?}

\author{
Markus Altena Davidsen* \\ University of Aarhus, Denmark \\ University of Leiden, Netherlands \\ m.davidsen@religion.leidenuniv.nl
}

\begin{abstract}
This review essay takes a critical look at the new field of "pagan studies" by examining the Handbook of Contemporary Paganism. It demonstrates that pagan studies is dominated by the methodological principles of essentialism, exclusivism, loyalism and supernaturalism, and shows how these principles promote normative constructions of 'pure' paganism, insider interpretations of the data, and theological speculations about gods, powers, and a special "magical consciousness." It seems thus that the methodological discussions in MTSR have little effect on pagan scholars. In the concluding discussion, I raise the questions why this is so, and how we might do better in promoting a naturalist and theoretically oriented approach to studying religion.
\end{abstract}

\section{Keywords}

Pagan studies, contemporary paganism, method and theory, the academic study of religion

Murphy Pizza and James R. Lewis (eds.) (2009). Handbook of Contemporary Paganism. In the series Brill Handbooks on Contemporary Religion 2. Series editor James R. Lewis. Leiden and Boston: Brill.

\section{Introduction}

Over the past quarter-century, it has been forcefully argued that scholars of religion should stop being "caretakers" (McCutcheon 2001) or "curators" (Lopez 1995) for specific traditions or religion in general. The religionist,

* I would like to thank Wim Hofstee for encouraging me to write this article in the first place and Egil Asprem and Armin W. Geertz for helpful comments on earlier drafts. 
phenomenological and hermeneutical orthodoxy, associated especially with Mircea Eliade, has been put on display as an "ideology" (Fitzgerald 2000) resting on theological (Asad 1993) or esoteric (Sedgwick 2004) suppositions. New "theses of method" (Lincoln 1996) have been offered for a reformed and critical study of religion. Nevertheless, almost every methodological and conceptual weakness in the old religionist approaches is reproduced and concentrated in the new field of pagan studies.

The main aim of this review essay is to present and evaluate the state of affairs in pagan studies using the Handbook of Contemporary Paganism as an illustration of the field in general. After a short introduction to contemporary paganism and pagan studies, the bulk of the text will consist of a close and critical reading of a selection of articles from the handbook, aimed at showing what is wrong with pagan studies. I will demonstrate how essentialism, exclusivism, loyalism and supernaturalism are the order of day and are made to pass for cutting-edge scholarship.

There are four reasons why such a critique of pagan studies is an urgent matter. Firstly, pagan scholars working from an explicitly pagan and insider point of view outnumber scholars who study paganism from a criticalnaturalist viewpoint. In the handbook, the numerical strength is 17 to 7 which seems to reflect the field in general. Secondly, this numerical superiority has allowed insider perspectives to dominate the study of paganism and to isolate and shield the field from theoretical and methodological discussions within the study of religion in general. This isolation has to be challenged from without and doing so should be a concern of our whole discipline. Thirdly, the dominance of insider approaches in the study of paganism makes it difficult for students and scholars who are not experts in the field to identify those excellent and academically sound publications on contemporary paganism which do exist. Fourthly, while paganism is particularly religionist, the problems of this field are illustrative of much of what is wrong in the academic study of religion in general.

Since the weaknesses of pagan studies are also present elsewhere in our discipline, I finish off by raising a general and pressing question: If pagan studies is largely unaffected by the insights and reorientations offered by those scholars who regularly publish in MTSR — and if pagan studies is only one among many ignorant fields-does that mean that we have failed for good in our effort to make the academic study of religion a scientific (in sense of a nonreligious and theoretically oriented) enterprise? I do not hope so, but I think that we could do better if we focused less on revealing the weaknesses of religionism and more on developing a workable alternative. I conclude by sketching my vision of such an alternative. 


\section{Handbook of Contemporary Paganism}

Contemporary paganism refers to a broad religious movement comprising Wicca, Druidry, Heathenry and a number of other branches which have taken form since the 1950s and began to self-identify as "neo-pagan" in the 1970s. In Europe, but not in North America, 'neo-paganism' has generally been replaced by 'contemporary paganism', 'modern paganism' or simply 'paganism' (these terms are often capitalized) as designations for the movement. The modern pagan movement experienced explosive growth in the 1990s, largely due to the Internet, and surveys suggest that there are now at least 500,000 pagans worldwide, most in the United States and other Anglophone countries (Berger; Lewis 2007). ${ }^{1}$ In the 21 st century, the growth rate has declined and paganism seems to have entered a period of consolidation (Ezzy; Ezzy and Berger 2009).

Since the late 1990s, the study of contemporary paganism has established itself as an independent research field, largely through the academic professionalization of pagan intellectuals who now hold university positions and offer degree programs in "Pagan Studies." A milestone in the development of the field was reached in 1999 when Equinox re-launched The Pomegranate and transformed what was originally a pagan theological amateur magazine into the first international, peer-reviewed, academic journal on paganism. The Handbook of Contemporary Paganism, the second volume in Brill's new series Brill Handbooks on Contemporary Religion, takes stock of the academic study of paganism after its first formative 15 years. ${ }^{2}$ Most of the leading researchers in the field have contributed, including Chas S. Clifton, Helen A. Berger, Michael York, Graham Harvey and Sabina Magliocco, and even though a few important figures (like Ronald Hutton and Joanne Pearson) are missing, it is warranted to view the 24 articles in the handbook as a reflection of the current constitution of paganism research.

\footnotetext{
${ }^{1}$ References without year (e.g., Berger; Ezzy) refer to articles in the Handbook of Contemporary Paganism. No independent entries are given for these articles in the bibliography.

2 Earlier overviews of modern paganism, like Margot Adler's Drawing Down the Moon (1979/1986) and Graham Harvey's Listening People, Speaking Earth (1997/2007) have been written from an insider point of view and for a pagan rather than an academic audience. The Handbook of Contemporary Paganism updates earlier handbook-like anthologies on contemporary paganism, such as Graham Harvey and Charlotte Hardman's Paganism Today (1996) and James R. Lewis's Magical Religion and Modern Witchcraft (1996). It reflects the professionalization of the field that all contributors to the current handbook are academics and/or hold a $\mathrm{PhD}$ while the two earlier handbooks included many contributions from non-academic pagan intellectuals.
} 
Since the handbook is huge (ix+649 pages) and since the aim of the review is not a comprehensive discussion of all contributions, I will to some extend treat the handbook as if it was written by two collective authors. Concretely, I will group the authors into two research programs, a religionist program with an insider perspective and supernaturalist ontology, and a scientific program with an outsider perspective and a naturalist ontology. The religionist, or loyalist-supernaturalist, research program within the study of paganism is the larger and more self-conscious one. Here paganism is studied from an explicitly pagan point of view, most often by pagans who have "gone native in reverse" by becoming academics, or, more rarely, by academics who have "gone native" by becoming pagans. ${ }^{3}$ The scientific, or critical-naturalist, research program is smaller, less self-conscious, less institutionalized, and comprised of researchers who typically study both paganism and other religions. These academics see themselves more as sociologists of religion, scholars of contemporary religion or historians in general than as scholars of contemporary paganism in particular.

Admitting that the categorization is more heuristic than definitive, I regard the seven contributions in the Handbook of Contemporary Paganism by Helen A. Berger, Sînn Reid, Sabine Magliocco, Marguerite Johnson, Carole M. Cusack, James R. Lewis and Mattias Gardell as belonging to the scientific program. The remaining seventeen religionist contributions can be placed along a continuum from a descriptive pole where the aim is to present ethnographies and historiographies as loyally and un-interpreted as possible, towards a theoretical pole where the goal is pagan interpretation, explanation, and theology. I consider the contributions by Nevill Drury, Henrik Bogdan, Chas Clifton, J. Lawton Winslade, Jenny Blain \& Robert Wallis, Douglas Ezzy, Hannah E. Johnston, Peg Aloi, and Ann-Marie Gallagher to be relatively descriptive. These articles need only minimal reinterpretation to be made commensurable with the critical-naturalist paradigm. The chapters by Robert Puckett, Susan Greenwood, Michael York, Jone Salomonsen, Graham Harvey, Dawne Sanson, Murphy Pizza, and Melissa Harrington, ${ }^{4}$ on the other hand, constitute the more theoretical and theological group of religionist contributions whose approach is incommensurable with the

\footnotetext{
${ }^{3}$ Melissa Harrington and Sylvia Shaw are examples of pagans who have become academics. Harrington refers to herself as a "native researcher" (2004: 79). Shaw dislikes the "colonialist" expression "going native," but readily identifies her research as "partisan" (2004: 136). For a testimony from a scholar gone native, see for instance Salomonsen (2004: 47). The academics of this research tradition generally refer to themselves as "Pagan scholars."

${ }^{4}$ I include Harrington's article (2007) on the relationship between contemporary paganism and new age in my analysis even though it did not appear in the Handbook of Contemporary Paganism, but in the Handbook of New Age, the first volume in the Brill Handbooks on Contemporary Religion series.
} 
critical-naturalist program and hence useful for scientific scholars of paganism mostly as source material. I will focus my critique on this last group of articles.

\section{Manufacturing Paganism: Essentialism and Exclusivism in Pagan Studies}

The editors point out that most pagans identify themselves as members of a particular tradition, i.e. as Wiccan, Druid, Heathen and so on, rather than perceiving themselves as part of the pagan movement in toto (2). In other words, 'pagan' is for many so-called pagans not their primary religious identity. As far as I can see, this fact invites a critical discussion of the very term 'contemporary paganism' and of the politics and interests involved in its construction. What counts as paganism for whom and why? Is paganism an invention of ecumenical and/or syncretistic Wiccans and Druids opposing a too rigid traditionalism? Or is paganism primarily a useful term for academics trying to carve out a new independent research field? Or none of these, or both? The editors do not raise any such questions (and neither do the contributors).

On the contrary, the editors adopt an essentialist approach and attempt to identify that 'real' essence which all pagans have in common despite their varying self-identifications. They identify this essence as a number of "shared Pagan values" (3). According to Pizza (and Lewis), ${ }^{5}$ these values include "acceptance of diversity, immanent divinity, and reverence for life on Earth" (3). Harrington suggests more elaborately that all pagans share a "Pagan ethos of reverence for the ancient Gods, including the divine Feminine, participation in a magical world view, stewardship and caring for the Earth, and 'nature religion'” (2007: 436). For pagan scholars, pagans are not those who selfidentify as 'pagan,' those who are affiliated with pagan institutions like the Pagan Federation, or those who belong to certain genealogically linked traditions, but a group of people who hold certain beliefs and, more importantly, certain values. What is happening here is a normative construction of the essence of contemporary paganism. The ideal of what paganism ought to be according to certain pagan intellectuals, is presented as how real or pure paganism is.

The ideal image of pagans as per definition tolerant, reverent, egalitarian and authentic is contradicted by the evidence in several contributions, but most clearly in the treatment of neo-Germanic paganism (Heathenry). The

${ }^{5}$ I suspect that main editor Murphy Pizza wields the pen here since she also insists on the existence of shared pagan values in her own contribution (499) while co-editor James R. Lewis's article sets out to deconstruct the Druid tradition. 
handbook includes both an article by Ann Marie Gallagher on "pagan fascist" groups in the UK and one by Mattias Gardell on racist Odinism in the US. The very existence of racist pagan groups, even if a numerical minority, challenges the picture of paganism as essentially tolerant and accepting of (racial) diversity. The article by Gardell furthermore points out (as the only one in the handbook) that the chauvinist or outright racist 'folkish movement' in Germany ("die völkische Bewegung") was an important predecessor of contemporary paganism (613). Also within Wicca, social reality does not always fit the ideal. Robert Puckett observes a tendency among Wiccan High Priests and Priestesses to try to gain power over their coven, a phenomenon so common that Wiccans have coined a name for it: the "High Priest(ess) syndrome" (134). Nevertheless, Puckett feels ideologically forced to identify the syndrome as a "pathological exception" to natural Wicca (134). It might well be that many High Priests and High Priestesses try to routinize Wiccan charisma into Amtscharisma, but Puckett firmly asserts that "the "normal" state of Wiccan charisma is democratic, magical, and non-routinized" (134). Puckett here insists that the essential and ideal Wicca (democratic, non-routinized) is more real than the observable and empirical (High Priest(ess) syndrome, Amtscharisma).

Essentialist ideas about what a 'real' pagan is influences the research agenda of pagan studies. The fact that most pagan scholars are themselves long-time practicing pagans leads to an overemphasis on established, communal and elite forms of paganism at the expense of more loosely organized, solitaire and/ or popular forms. I think that the omission of three central issues in the handbook is telling. Firstly, no single chapter is devoted to a discussion of solitaire practitioners despite the fact that this group accounts for at least half the total number of pagans (Berger: 167). Secondly, pagan use of the Internet is not systematically discussed even though the Internet is identified as important for the member explosion in the 1990s (Berger) and as increasingly important for pagan community maintenance (Ezzy). ${ }^{6}$ Thirdly and related, it is regrettable that none of the articles treat the widespread pagan use of fiction as inspirational texts. This omission stands in stark contrast to the general (but embarrassed) agreement in the field that the works of J.R.R. Tolkien, Robert Heinlein, Marion Zimmer-Bradley and others have been crucial for the development of paganism, and that such movies as The Craft (1996) and TV-shows

\footnotetext{
${ }^{6}$ A few studies have been done on pagans and the Internet by Cowan (2005) and Ezzy and Berger (2009). In a number of recent publications, Berger and Ezzy have furthermore opened up the field of (largely Internet-mediated) 'teenage witchcraft' (Berger and Ezzy 2007; 2009).
} 
like Charmed (1998-2006) were important causes of the explosion of the number of (young) pagans in the late 1990s and early 2000s. ${ }^{7}$

It seems that one of the reasons why solitaire, internet-based and/or popular forms of paganism are almost excluded from study is that they combine pagan ideas and practices with those of other religious traditions, thereby challenging normative notions of what counts as authentic paganism and what does not. Especially popular combinations of paganism with new age or Christianity are seen as problematic_-or even polluting_-by some pagan scholars. In her article on the relationship between new age and paganism, Harrington contrasts authentic, communal and ethical paganism (Wicca) with what she sees as commercial, commodified, and materialistic new age (2007: 441-442 and 448-449). This raises the question what to do with the many self-identified pagans who are solitaires and work magic for materialistic ends. Drawing on Ezzy's work, Harrington disqualifies such popular paganism as "commodified witchcraft" (cf. Ezzy 2001) or "New Age witchcraft" (cf. Ezzy 2003) and hence not real paganism. Harrington takes issue with Paul Heelas (1996) who dared to say that some new agers use "Wiccan rituals," such as circle casting. According to Harrington, Wiccan rituals used outside of institutionalized Wicca cease to be Wiccan (and pagan). In the case of new age witchcraft, it would be okay to talk of "Wiccan-derived rituals," (2007: 445, my emphasis), and researchers should use this term because "Wiccans might prefer" that (2007: 445). Which Wiccans? Harrington speaks on behalf of a certain group of elite Wiccans who are doing identity management and boundary-work to force less prestigious co-religionists out of the Wiccan/pagan category and into the pejorative new age category. Such religious identity politics are highly interesting, but hardly something that independent and critical scholarship can engage in. ${ }^{8}$

Harrington also considers it impossible to be a pagan and a Christian at the same time, but curiously asserts that being a Christian new ager is perfectly possible (2007: 450). Christianity and new age are thus denied the exclusivism granted to paganism. Despite the fact that a Christian pagan sounds like an oxymoron, Harrington's normative statement on its impossibility is disproved by the evidence. $9.2 \%$ of the pagans who participated in the so-called Pagan

\footnotetext{
7 So far, pagan use of fiction has been very preliminarily treated by Harvey (2000; 2006), but many scholars have pointed out that work needs to be done here. Chas Clifton remarks that "[t]he interaction between science/speculative fiction and Wicca and other forms of Paganism deserves further exploration. It is a book waiting to be written, possibly several books" (2006: 4).

8 That is not to say that science does not know its own identity politics or boundary-work, as the present essay is a prime example of. On the notion of boundary-work, see Gieryn (1983).
} 
Census in the mid-1990s self-identified as Unitarian Universalist Pagans, that is as members of a liberal Christian church (Berger: 167). There is also a significant overlap between feminist Christian theology and feminist Witchcraft/ Goddess spirituality. This is briefly mentioned by Cusack (350-351) and Salomonsen (363), but regrettably not treated in depth. ${ }^{9}$

\section{Insider Interpretations: Loyalism in Pagan Studies}

Another recurrent problem, besides essentialism and exclusivism, is what we can call methodological loyalism with regard to informants and subject matter. This position is most clearly articulated in Jone Salomonsen's "method of compassion." Inspired by the anthropologist Katherine P. Ewing (1994), Salomonsen states:

"Compassion" in this context does not refer to a wholesale positive embrace, nor to passionate criticism and arguing, but to something in between: to honesty. It designates an attitude in which belief is taken seriously, both cognitively and emotionally. This means leaving behind the anthropological "method of pretension" (Salomonsen 2004: 50).

Given that Salomonsen tries to formulate a middle-ground between embrace and criticism, it might sound a bit strong to characterize her position as loyalism, but the term is warranted for two reasons. Firstly, the actual Archimedes point of pagan studies lies much closer to "positive embrace" of the informants' statements than to "passionate criticism" of them. Secondly, that "belief is [to be] taken seriously [...] cognitively," means nothing else than that the belief of the informants has to be believed also by the scholar.

We can witness the method of compassion in action in Salomonsen's own contribution to the handbook where she discusses the initiation practice of the Reclaiming Witches in San Francisco. According to Salomonsen, this initiation is

radically different from conversion to a sect, first of all in terms of pedagogic. In initiations, the authority structure is a conscious and time-limited one, set up for the purpose of personal refinement to help the individual develop inner authority, love and trust. In sectarian conversion this may or may not be the case, but an often-heard version is that the convert is set in a continuous relationship with an omnipotent, male authority figure (371).

Both Salomonsen's negative picture of "conversion to a sect" and her positive description of the Reclaiming initiation are problematic, and the two are

9 Interested readers can turn to Manning (1996). 
certainly not "radically different." Conversion to new religious movements in general is rarely as coercive and absolute as Salomonsen suggests, but rather gradual, fragile, reversible and often temporary (cf. Snow \& Machalek 1984; Rambo 1993). On the other hand, power and authority clearly play a role in initiation into the Reclaiming tradition. Salomonsen tells us that a lot is required of a candidate before initiation: The candidate must have been a member for at least a year and a day to begin the initiation process and has to pass a range of challenges which are arbitrarily chosen by the initiators (372). Salomonsen's examples include the challenge to abstain from drinking beer for a year (372), and the request of being nude at rituals (380). It usually takes at least a year to complete the challenges which supposedly "come from the goddess via the initiator" (372), and over-coming them is seen as the necessary spiritual self-development which makes one ready to "surrender" (370 and 387 ) one's own "I" to the Goddess in the actual initiation ritual so it can be "remould [...] into a new becoming" (365). The initiators can deny initiation (372) or back out at any time (378). It does not occur to Salomonsen to question the (ab)use of power or to consider the challenges as a test of the member's loyalty to the group. But as far as I can see, and given the duration and arbitrariness of the preparation process, the only thing differentiating initiation into Reclaiming Witchcraft from conversion to a sect as Salomonsen describes it, is the gender of the authority figure(s).

Salomonsen also thinks that her article can "document how the actual preparation for initiation have $[s i c]$ the power to transform-being a performative and emotional act of commitment and devotion, rather than being a question of dogmatically joining prearranged belief systems" (376). There is good reason to challenge this. Salomonsen seems to have forgotten what she has just told the reader, namely that (a) several classes of training into a specific belief system are required before one can even ask for initiation (372), and (b) that secret knowledge of this particular belief system is the very goal of the initiation, at least for the particular initiate we follow in the article (374-375 and 387). Salomonsen is trying to force her data into an already given insider interpretation of the situation. When raw data and theological interpretation clashes, she sides with theology. Fortunately, she provides enough data for the reader to form his own critical opinion. ${ }^{10}$

Another example of loyal reproduction of the self-description and rationalizations of the informants is found in Murphy Pizza's discussion of children in

${ }^{10}$ For a serious discussion of conversion to paganism, the reader can turn to Sían Reid's strong article in the handbook and to Manning (1996). Both bypass the often repeated pagan studies claim that people do not convert but 'come home' to paganism (e.g., Harvey 1999; Harrington 2000) and insist that conversion to paganism is an instance of conversions in general. 
paganism. Pizza takes issue with Helen Berger's thesis that the increasing number of children in pagan communities contributes to a routinization of pagan spontaneity or creativity (Berger 1995; 1999: ch. 6). But Pizza's account fails to convince. In the Twin Cities pagan community (Paganistan), she observes that the inclusion of children into the pagan community leads to all kinds of accommodations, but she interprets these as signs of "formidable creativity" rather than instances of routinization and homogenization (499). She does so even when pagans systematize socialization of their children with the aim of "maintaining community and cultural transmission" (504) or when pagans try to overcome internal differences by identifying shared values (499 and 505). Pizza sticks to the pagan self-understanding as creative, innovative and distinctive no matter the facts.

These examples illustrate a loyalist tendency of pagan scholars to not question insider interpretations, but to present them as if they were bare facts. They further show that this loyalism supports the ontological essentialism and exclusivism discussed above: Pagan scholars insist on paganism's distinctiveness to a degree where pagans 'come home' where others 'convert,' pagans use Goddess-given tests of devotion where sect-leaders abuse power, and pagans invent where others appropriate.

\section{Pagan Theology: Supernaturalism in Pagan Studies}

Four of the contributions to the handbook not only loyally report the supernatural assumptions of their informants, but also theorize informed by a supernaturalist ontology. Two of the absolute heavyweights in pagan studies, Graham Harvey and Michael York, see it as their task to provide something like a systematic pagan theology. Harvey's theology is "animistic" and counts on the existence of a large number of "other-than-human persons" (397-398 and 402) with whom humans can communicate. The other-than-human persons include not only "trees, animals, birds and water-courses," but also "otherworld-beings" or "faeries" (405). This "new animism" differs from Edward Tylor's "old animism" in its assertion that the belief in other-thanhuman persons is true and not false as Tylor would have it (394-395). Harvey draws practical conclusions from this ontology: In principle, we should abandon lifestyles which are "inescapably dangerous to other-than-human persons" (407). If it is not feasible to stop our "killing and eating" at present, at least our destructive actions require "careful negotiation" with the other-thanhuman persons by means of animist shamanry (407). That is, we should let shamans negotiate with the spirits on behalf of society about the amount of 
natural resources humans can reasonably exploit without damaging the otherthan-human persons too much.

York simply calls his theology "Pagan." It is not animistic (referring to beings) like Harvey's, but rather dynamistic (referring to a power). York's main point is that gods and spirits (together the "elven," 306) do not exist as personal entities, but as "particular energy complex[es]" (296). Ultimately, all human conceptualizations of the divine are reducible to a single complex of immaterial energy. Elsewhere in the handbook, Robert Puckett compares this energy complex with the notion of 'mana' (132). For a scholar of religion looking from without, it is interesting to see how contemporary Pagan theologians refer to classics such as Tylor on animism, Marett on mana, Hubert and Mauss on magic etc. in order to make sense of their own beliefs. Especially York does so for reasons of legitimation. By demonstrating modern paganism's likeness to primitive religion, he seeks to construct paganism as the "root religion," i.e. the natural and most pure form of religion (285; see also York 2004).

The two other explicitly supernaturalist contributions are written by Susan Greenwood and Dawne Sanson. Greenwood is the author of a number of much appraised (in pagan studies circles) books on the "magical consciousness" (e.g., Greenwood 2005). Greenwood does not define the term in her own contribution, but luckily Sanson, a self-identified "naturopath" whose article argues for the superiority of shamanism as psychotherapy, quotes Greenwood's definition. Magical consciousness, then, is

a particular form of ASC [Altered State of Consciousness] in which a "participatory and expanded aspect of consciousness" allows reciprocal communication to occur between other-than-human and human beings, thus promoting "an awareness of holistic interconnection and cosmologies" (446; inner quotes from Greenwood 2005: 91).

In plain English: magical consciousness is a state of mind in which one can access the spirit world, talk with spirits and experience a sense of connectedness with them. Greenwood's 'theory' amounts to a supernaturalist epistemology which fits with the supernaturalist ontological speculations of Harvey and York.

Greenwood's article recounts how she and a group of other pagans entered the magical state of consciousness in a forest in East Anglia and connected with the Wild Hunt of Herne, a group of ghosts who hunted them through the forest. The reader is asked to believe in the reality of these spirits, and is further told that the shaman Gordon MacLellan "has been initiated by the Wild Hunt" in an elaborate way including "shamanic dismemberment" (213). 
Jumping from the particular to the universal, Greenwood engages in a discussion with anthropologist Maurice Bloch. Bloch has argued that Madagascans have a dualistic worldview with a sharp division between the world of the living and the world of the spirits. According to Greenwood, this can not be true, for all nature spiritualities, i.e. historical and contemporary paganism and indigenous religions, have holistic rather than dualistic worldviews. If one thinks differently, as Bloch does, it can only be because one has adopted "Western scientific attitudes to nature [which] stem from being physically cut off from living on the land" (219). How can Greenwood be sure that she knows the Madagascan worldview better than Bloch? Her mistaken confidence rests on three notions: Firstly, her interpretation of indigenous African cultures is determined by a cultural primitivism, i.e. the romantic idea that the most authentic and desirable life is the one lead by contemporary indigenous peoples. ${ }^{11}$ Secondly, Greenwood sees paganism as a 'nature religion' and therefore as essentially identical to the religions of the indigenes. Finally, since the indigenes also enter the magical consciousness, they have the same insight into the ontology of the world as herself and hence must hold a holistic worldview. In other words, Greenwood argues that being a nature religionist herself gives her privileged epistemological access to the minds and cultures of indigenous co-religionists. Sadly, projection of the researcher's ideology unto the researched indigenes, legitimized with metaphysical speculations about essential qualities and identities, has here supplanted a rational argument based on accurate ethnography. ${ }^{12}$

\section{What is Wrong With Pagan Studies?}

This review essay set out to demonstrate what is wrong with pagan studies, and out of the critical discussion of the handbook emerges the following answer: Most scholarship within pagan studies rests on the methodological principles of essentialism, exclusivism, loyalism, and supernaturalism. Consequently, pagan scholarship advances idealized notions of paganism's essence, insider interpretations of social processes, and pagan theology. In other words, pagan studies contributes more to the development and promotion of

\footnotetext{
11 York and Harvey are also primitivists, but York's primitivism (at least in his contribution to the handbook) differs from Greenwood's and Harvey's by locating the ideal condition of human life in the past (though it can be recovered) rather than among contemporary indigenes. See Geertz (2009) for a brief and recent discussion of primitivism, especially against Harvey.

12 See Jensen (2011: 35-36) for a critique of the notion that sharing a 'cultural essence' provides one with a privileged epistemological position.
} 
paganism than to the critical study of the modern pagan movement. A sound alternative exists which I have called the scientific or critical-naturalist study of paganism. The scholars within this research program are painfully aware of the methodological shortcomings of their religionist colleagues, but far from being able to persuade the religionists to change their ways, they find themselves inhabiting the margins of the field as a tolerated minority.

If this analysis of pagan studies sounds familiar, it is probably because similar problems, in stronger or weaker measures, are present in most of the fields that make up the academic study of religion. Rather than rehearsing the debates between religionists and naturalists, I would like to conclude with a discussion of why we-the contributors to MTSR and all the others who seek to advance critical inquiry and theoretical ambition-fail to reach the religionists within our discipline. ${ }^{13}$ Both institutional and academic aspects must be taken into account to explain our relative failure and to sketch how we might do better.

\section{Why Are These Things Wrong and What Can Be Done?}

Let me begin the exploration of institutional aspects by stating a well-known fact: The academic study of religion is a fragmented discipline in which most scholars identify more strongly with their field of specialization than with their mother-discipline. These 'field identities' are sustained by independent conferences, journals, and in some cases even field specific degree programs and departments. Pagan studies is a good example of a field with a strong field identity.

Field-directedness is not a problem if it is tempered by initiatives and forces promoting the integration of fields into the discipline of the study of religion. But rather than countering the fragmentation of the study of religion, many universities institutionalize field identities by locating research on particular religious traditions under area studies and/or by systematically appointing insiders (Jews for Jewish studies, pagans for pagans studies and so on). As a result, many scholars of religious traditions lack an identity as scholars of religion and hence an interest in method and theory as it is formulated on discipline level. A comment from some of the participants in a recent $\mathrm{PhD}$ workshop on method and theory in the Netherlands illustrates the point nicely. They said that though methodology was an interesting "theme," it was

\footnotetext{
${ }_{13}$ For an overview of the particularly heated North American debates in the 1980s and 1990s, see McCutcheon (1999).
} 
not directly relevant for their particular projects. Clearly, these young scholars viewed method and theory as a field apart rather than as the shared foundation of the academic study of religion.

The fragmentation of our discipline into fields, the systematic appointments of insiders, and the view that method and theory is just an optional theme are all very real problems that we have to tackle, and that have to be tackled (primarily) politically. Writing about these things is not enoughbattles have to be fought and won on boards and in commissions on various levels. I brought up our Dutch PhD workshop because I think that PhD education is a crucial place to focus our effort. A single workshop is not enough, but if method and theory were better integrated into $\mathrm{PhD}$ curricula and emphasized as an indispensable component in the evaluation of $\mathrm{PhD}$ theses, we would have an effective instrument with which to educate and influence future generations of scholars, and through them the institutes where they subsequently find work.

Institutional issues only partly explain the lack of impact of critical-naturalist method and theory into the discipline. Another reason is that religionists consider us unable to offer a positive alternative to their way of studying religion. We can regret it, but it is not difficult to explain why it is so. Simplifying a complex matter, we can say that while religionists lack a sound methodology, they at least have a clear idea about what their object-religion-is, namely the human response to the divine or sacred. Such a shared notion of what religion is, however problematic it might be, has the virtue of nurturing a collective identity. The critical study of religion which has emerged during the last 25 years has turned this situation on its head. It has developed a sophisticated methodology, promoting the critical examination of both religions and the academic study of religions, but in the process the very category religion and any attempt to theorize it have become suspect. Critical theorists no longer study religion or religious activity as such, but aim to analyze how people talk about religion, which social constructions people label religion, and how the resulting discourses serve to legitimize power structures. This is all very important, but leaves much out of the question. And worse, the deconstruction of religion bereaves the academic study of religion of its common object, thus further threatening the fragile identity of the discipline. It is not surprising that religionists are unwilling to adopt an approach that requires them to give up both their methodology, object, and identity.

If religionism is clear on its object, but weak on methodology, and critical theory is strong on methodology, but unclear on its object, it raises the question whether the two virtues could be combined in a position offering a brighter prospect for the academic study of religion in general and requiring 
less sacrifice for religionists to adopt. In fact, such a positive program exists, for instance in the work of Martin Riesebrodt (2010) and Ivan Strenski (2006). Rather than seeing themselves as followers or adversaries of Eliade, these scholars aim to develop the study of religion in dialogue with the more constructive classics Weber and Durkheim. They dare to define, but see their definitions as analytical instruments which help us identify the elementary forms and processes of religion. The aim of their positive program is to further our understanding of these forms and processes by asking questions about the logic of religious practice, the social functions of religion, the modalities of belief, the social construction of persuasiveness and plausibility, and so on. Even within paganism studies a few very good studies of this character have been produced, most notably Helen Berger's work on routinization $(2005 ; 2009)$ and Tanya Luhrmann's on interpretive drift (1989). I would like to invite all scholars of paganism to take these works as paradigmatic exemplars for their own research.

The critical and positive programs in the study of religion supplement each other and the discipline needs both. Nevertheless, there are two reasons why we should use relatively more effort on promoting the positive program and relatively less on the critical program. Firstly, only the positive program provides the shared theoretical objects we need in order to build and sustain a discipline identity as scholars of religion. Secondly, by offering theoretical and conceptual models instead of deconstruction and criticism of the religionist position, the positive program puts us in a stronger position to demonstrate the relevance of method and theory also to religionists. In sum, the positive and theoretical study of religion is both the soundest scholarly approach and the most promising instrument in promoting the integration of our discipline and the permeation of method and theory throughout it.

\section{References}

Adler, Margot (1986). Drawing Down the Moon: Witches, Druids, Goddess-Worshippers, and Other Pagans in America Today. Revised and expanded edition. London: Penguin. First edition 1979.

Asad, Talal (1993). Genealogies of Religion: Discipline and Reasons of Power in Christianity and Islam. Baltimore \& London: The Johns Hopkins University Press.

Berger, Helen A. (1995). Routinization of spontaneity. Sociology of Religion 56(1): 49-62. (1999). A Community of Witches: Contemporary Neo-Paganism and Witchcraft in the United States. Columbia: University of South Carolina Press.

Berger, Helen A. and Douglas Ezzy (2007). Teenage Witches: Magical Youth and the Search for the Self. New Brunswick, NJ and London: Rutgers University Press.

- (2009). Mass media and religious identity: A case study of young witches. Journal for the Scientific Study of Religion 48(3): 501-514. 
Clifton, Chas S. (2006). Her Hidden Children: The Rise of Wicca and Paganism in America. Lanham, Boulder, New York, Toronto, and Oxford: AltaMira Press.

Cowan, Douglas E. (2005). Cyberhenge: Modern Pagans on the Internet. New York and London: Routledge.

Ewing, Katherine P. (1994). Dreams from a saint: Anthropological atheism and the temptation to believe. American Anthropologist 96(3): 571-583.

Ezzy, Douglas (2001). The commodification of witchcraft. Australian Religion Studies Review 14(1): 31-44.

- (2003). New Age witchcraft? Popular spell books and the re-enchantment of everyday life. Culture and Religion 4(1): 47-65.

Ezzy, Douglas and Helen A. Berger (2009). Witchcraft: Changing patterns of participation in the early twenty-first century. The Pomegranate: The International Journal of Pagan Studies 11(2): 165-180.

Fitzgerald, Timothy (2000). The Ideology of Religious Studies. New York \& Oxford: Oxford University Press.

Geertz, Armin W. (2009). Indigenous religions: A review essay. Anthropos: Internationale Zeitschrift für Völker- und Sprachenkunde 104: 198-202.

Gieryn, Thomas F. (1983). Boundary-work and the demarcation of science from non-science: Strains and interests in professional ideologies of scientists. American Sociological Review 48: 781-795.

Greenwood, Susan (2005). The Nature of Magic: An Anthropology of Consciousness. Oxford: Berg.

Griffin, Wendy (2004). The deosil dance. In Jenny Blain, Douglas Ezzy, and Graham Harvey (eds.), Researching Paganisms, 59-67. Walnut Creek, Lanham, New York, Toronto, and Oxford: AltaMira Press.

Harrington, Melissa (2000). 'Conversion' to Wicca? Diskus 6. Available at http://web.unimarburg.de/religionswissenschaft/journal/diskus

- (2004). Psychology of religion and the study of Paganism. In Jenny Blain, Douglas Ezzy, and Graham Harvey (eds.), Researching Paganisms, 71-84. Walnut Creek, Lanham, New York, Toronto, and Oxford: AltaMira Press.

(2007). Paganism and the New Age. In Daren Kemp and James R. Lewis (eds.), Handbook of New Age, 435-452. Leiden and Boston: Brill.

Harvey, Graham (1999). Coming home and coming out Pagan (but not converting). In Christopher Lamb and M. Darrol Bryant (eds.), Religious Conversion: Contemporary Practices and Controversies, 233-246. London: Cassell.

(2000). Fantasy in the study of religions: Paganism as observed and enhanced by Terry Pratchett. Diskus 6. Available at http://www.uni-marburg.de/religionswissenschaft/journal/ diskus

- (2006). Discworld and otherworld: The imaginative use of fantasy literature among Pagans. In Lynne Hume and Kathleen McPhillips (eds.), Popular Spiritualities: The Politics of Contemporary Enchantment, 41-52. Aldershot, UK and Burlington, VT: Ashgate.

- (2007). Listening People, Speaking Earth: Contemporary Paganism. Second edition, corrected and expanded. London: Hurst \& Co. First edition 1997.

Harvey, Graham and Charlotte Hardman (eds.) (1996). Paganism Today: Wiccans, Druids, the Goddess and Ancient Earth Traditions for the Twenty-First Century. London and San Francisco: Thorsons.

Heelas, Paul (1996). The New Age Movement: The Celebration of the Self and the Sacralization of Modernity. Oxford and Cambridge, MA: Blackwell Publishers.

Jensen, Jeppe Sinding (2011). Revisiting the insider-outsider debate: Dismantling a pseudoproblem in the study of religion. Method and Theory in the Study of Religion 23(1): 29-47. 
Lewis, James R. (ed.) (1996). Magical Religion and Modern Witchcraft. Albany, NY: State University of New York Press.

- (2007). The Pagan explosion: An overview of select census and survey data. In Hannah E. Johnston and Peg Aloi (eds.), The New Generation Witches: Teenage Witchcraft in Contemporary Culture, 13-23. Aldershot, England and Burlington, VT: Ashgate.

Lincoln, Bruce (1996). Theses on method. Method and Theory in the Study of Religion 8(3): 225-227.

Lopez, Donald S., Jr. (ed.) (1995). Curators of the Buddha: The Study of Buddhism under Colonialism. Chicago and London: The University of Chicago Press.

Luhrmann, Tanya M. (1989). Persuasions of the Witch's Craft: Ritual Magic in Contemporary England. Cambridge, MA: Harvard University Press.

Manning, Christel Johanna (1996). Embracing Jesus and the Goddess: Towards a reconceptualization of conversion to syncretistic religion. In James R. Lewis (ed.), Magical Religion and Modern Witchcraft, 299-326. Albany, NY: State University of New York Press.

McCutcheon, Russell T. (ed.) (1999). The Insider/Outsider Problem in the Study of Religion: A Reader. London and New York: Cassell.

- (2001). Critics, not Caretakers: Redescribing the Public Study of Religion. Albany: State University of New York Press.

Rambo, Lewis R. (1993). Understanding Religious Conversion. New Haven: Yale University Press.

Riesebrodt, Martin (2010). The Promise of Salvation. Translated from German, Cultus und Heilsversprechen: Eine Theorie der Religion. Chicago: University of Chicago Press.

Salomonsen, Jone (2004). Methods of compassion or pretension? The challenges of conducting fieldwork in modern magical communities. In Jenny Blain, Douglas Ezzy, and Graham Harvey (eds.), Researching Paganisms, 43-58. Walnut Creek, Lanham, New York, Toronto, and Oxford: AltaMira Press. Reprint from 1999, The Pomegranate: A New Journal of Neopagan Thought 8: 4-13.

Sedgwick, Mark (2004). Against the Modern World: Traditionalism and the Secret Intellectual History of the Twentieth Century. New York: Oxford University Press.

Shaw, Sylvie (2004). At the water's edge: An ecologically inspired methodology. In Jenny Blain, Douglas Ezzy, and Graham Harvey (eds.), Researching Paganisms, 131-146. Walnut Creek, Lanham, New York, Toronto, and Oxford: AltaMira Press.

Snow, David and Richard Machalek (1984). The sociology of conversion. Annual Review of Sociology 10: 167-190.

Strenski, Ivan (2006). The New Durkheim. New Brunswick: Rutgers University Press.

York, Michael (2004). Paganism as root-religion. The Pomegranate: The International Journal of Pagan Studies 6(1): 11-18. 